\title{
anemon
}

Muş Alparslan Üniversitesi Sosyal Bilimler Dergisi

Journal of Social Sciences of Muş Alparslan University

Yıl/Year: 2016 • Cilt/Volume: 4 • Sayı/Number: 2

ISSN: 2147-7655 • e-ISSN: 2149-4622

ÖZGÜN ARASSTIRMA • ORIGINAL ARTICLE

\section{Çevreci Tüketicilerin Değer Temelli Bölümlendirilmesi: Çevreci Kadın Tüketiciler Üzerine Bir Araştırma}

\author{
Hatice AYDIN 1,a \\ ${ }^{1}$ Yrd. Doç. Dr., Muş Alparslan Üniversitesi, İ̈BF, İşletme Bölümü - Muş/ Türkiye.
}

Öz

Sınırsız istek ve beklentileri olan tüketicilerin bulunduğu heterojen pazarlarda tüm tüketicilerin istek ve beklentilerinin tam anlamıla karşılanabilmesi zordur. Günümüz firmalarının rekabette üstünlük ve farklılık sağlayabilmeleri, hedef seçtikleri pazar bölümleri için doğru ve etkin pazarlama stratejileri geliştirmeleri ile mümkündür. Firmalar hedef pazar bölümlerini belirlerken birçok değişkeni dikkate almaktadır. Çevreci tüketim davranışlarında etkili olan kişisel ve tüketim değerleri, firmaların pazarı bölümlemede yararlandıkları önemli değişkenlerdendir. Bu çalışmada, çevreci kadın tüketicilerin tüketim ve kişisel değerleri açısından alt bölümlere ayrılıp ayrılmadıklarını belirlemek amaçlanmıș ve bu amaç doğrultusunda kümeleme analizi yapılmıștır. Ayrıca elde edilen kümeler arasında demografik özellikler itibari ile anlamlı farkın olup olmadığı diskriminant analizi ile test edilmiştir. Araştırma, Doğu Anadolu Bölgesi/Muş ilinde 18 yaş üstü kadın tüketicilere uygulanmıştır. Analiz sonucunda, çevreci kadın tüketicilerin kişisel ve tüketim değerleri açısından iki kümeye ayrıldıkları tespit edilmiştir. Birinci kümenin öne çıkan kişisel değeri, öz aşkınlık iken, ikinci kümenin ise öz gelişmişliktir. Ayrıca, birinci kümenin fonksiyonel tüketim değeri ve ikinci kümenin sosyal ve yaratıcı tüketim değerleri öne çıkmaktadır. $\mathrm{Bu}$ kümelerin demografik özelliklerden sadece yaş değişkeni açısından aralarında anlamlı farklılığın olduğu tespit edilmiştir.

\section{Anahtar Kelimeler}

Öz-Aşkınlık, Öz-Gelişmişlik, Tüketim Değerleri, Kişisel Değerler, Yeşil Tüketim

\footnotetext{
a Sorumlu Yazar/Correspoding Author: Muş Alparslan Üniversitesi Kampüsü, İktisadi ve İdari Bilimler Fakültesi, İşletme Bölümü, 49250, Muş / Türkiye.

e-posta: aydinhtice@gmail.com 


\title{
Value-Based Segmentation of Green Consumers: A Study on Green Women Consumers
}

\begin{abstract}
It is difficult to meet fully all the requirements and expectations of consumers in heterogeneous market where there are consumers' unlimited demands and expectations. If today's companies want to gain some competitive advantage, they should develop accurate and effective marketing strategies for their chosen target market segments. Companies consider many variables to determine the target market segments. Personal and consumption values are important factors which are used for market segmentation. In this study, it is aimed to determine whether female consumers are divided into sub-groups regarding their personal and consumption values and in order to do this, cluster analysis is made. In addition, to determine whether there is a significant difference between the clusters in terms of demographic features, discriminant analysis is made. Research has been applied in Eastern Anatolia Region (Mus province) to female consumers over 18. As a result of the study, it is determined female consumer are divided into two sub-groups in terms of their personal and consumption values. In the first cluster, consumers have self-transcendence personal value and in the second cluster they have self-enhancement value. Also for the first cluster, functional consumption value is more important and for the second cluster social and epistemic value are more important. And only in terms of age, variable differences between these clusters were found.
\end{abstract}

\section{Keywords}

Self-Enhancement, Self-Transcendence, Consumption Value, Personal Value, Green Consumption

\section{GİRIŞ}

Teknolojik gelişmelerle paralel olarak meydana gelen aşırı üretim beraberinde tüketimin dengesizce artışını getirmiştir. Tüketim ve üretimdeki aşırı artışın en önemli sonucu doğal kaynakları olumsuz etkilemesi olmuş ve ekolojik tahribat hızla artmıştır. Başta işletmeler ve tüketiciler olmak üzere tüm insanlar küresel 1sınma, su ve hava kirliliği gibi doğada meydana gelen problemlerden sorumludurlar. Çünkü insanların sorumsuz davranışları doğada kötü sonuçlar meydana getirmektedir. Ancak günümüz tüketicisi çevrenin korunması konusunda daha duyarlı davranmakta ve alışılmış davranışlarını terk etmektedir. Bu duyarlılığın yeni adı sürdürülebilir tüketim ya da çevreci tüketim olarak ifade edilmektedir. Çevreci tüketim ile tüketiciler çevreyi ve doğal kaynakları koruma sorumluluğu taşımaktadırlar (Kalafatis vd., 1999). Tüketiciler arasında yaygınlaşan genel kanı, çevre dostu tüketimin, yaşamın devamlılığı için zorunlu olduğudur. Dolayısıyla günümüzde tüketim, bilinçten öte yaşam biçimi haline gelmiştir. Bu durum işletmelerin de alışıla gelen üretim anlayışlarındaki değişimi hızlandırmalarını sağlamıştır. Günümüz işletmeleri, özellikle enerji tasarrufu sağlayan ve geri dönüştürülebilir çevreci ürünler üretmeyi yaşam felsefeleri haline getirmeye başlamışlardır. Ancak işletmelerin, bununla 
sınırlı kalmayıp artan tüketici duyarlılığına cevap veren yeşil tüketime yönelik pazarlama stratejileri geliştirmeleri gerekmektedir (Ko vd., 2013: 1709). Tüketim ve üretimin bu denli değiştiği bir dönemde işletmeler çok farklı beklentileri olan çevreci tüketiciler arasından hedef pazarlar belirlemelidirler. Böylece hedef seçtikleri pazardaki tüketicileri alt bölümlere ayırma, benzer istekleri olanları daha yakından tanıma, pazarlama stratejilerinde daha etkin olma, doğru kararlar verme ve müşteri beklentilerini uygun bir şekilde yerine getirme imkânı elde edebilirler. İşletmeler, pazar bölümlemede demografik, psikografik ve davranışsal değişkenler başta olmak üzere birçok değişkeni dikkate alırlar (Kotler, 1997: 31). Ancak bölümlemede en iyi yol, tek bir değişken yerine amaca uygun olan değişkenlerden birkaçını birlikte değerlendirmektir (Ünal vd., 2008: 212).

Tüketicilerin bir üründe aradıkları ilk şeyin ürünün özelliği olduğu ve ürünlerde önemsedikleri özelliklerin ise sahip oldukları değerlere göre şekillendiği dikkate alındığında, bölümlemede yararlanılabilecek önemli değişkenlerden birinin de değer olduğu söylenebilir (Sheth vd., 1991b). Değer, insan davranışlarına rehberlik eden ilkeler, bir şeyin arzu edilebilirliği hakkındaki inançlar, insanın tercihine göre davranmak isteme eğilimi, belirli durumları diğerlerine tercih etme durumu ve bireyin tercih kriterleri şeklinde ifade edilmektedir (Gutman, 1982: 60; Byrd, 2002: 56; Grey, 2005: 22; Choi, 2005: 4; Ramos, 2006: 36). Kişinin sahip olduğu değerler, davranışlarına yön vermektedir. $\mathrm{Bu}$ nedenle sahip olunan değerlerin, tüketicilerin çevresel duyarlılıklarındaki artışta etkili olduğu düşünülmektedir. Aynı uyarıcılara tüketiciler, farklı tepkiler verebilmektedir. Psikolojik faktörlerden olan kişisel değerler, tüketicilerin tepkilerinde farklılık yaratan değerlerden biridir. Dolayısıyla, tüketicilerin ürünlerde önemsedikleri özelliklerin birbirinden farklı olması da kişisel özelliklerini ifade eden kişisel değerlerinden kaynaklanabilmektedir. Kişisel değer, "kişilerin hayatlarına yön veren, önem derecesi duruma göre değişen, kişilerin ulaşmak istedikleri amaçlar" olarak ifade edilmektedir. Bu amaçlar tüketicilerin her türlü seçim kararlarını etkilemektedir (Schwartz,1994: 20-21). Tüketiciler, kişisel değerleri ile tutarlılık gösteren satın alma davranışı sergilemektedir (Shim ve Eastlick, 1998). Örneğin evrensellik değeri baskın olan tüketiciler diğerlerine göre daha çevreci davranabilmektedir. Bu etkilerinden dolayı "kişisel değerler" kavramı son yıllarda pazarlama alanında üzerinde sıklıkla durulan ve bölümlemede yararlanılan değer kavramlarından biri haline gelmiştir (Kamakura ve Mazzon, 1991). Kişisel değerlerin tüketici satın alma davranışlarını açıklamada kullanılacak en güçlü değişkenlerden olduğu da öne sürülmektedir (Thogersen ve Ölander, 2002). Dolayısıyla tüketicilerin çevreci ürün özelliklerini değerlendirirken de kişisel değerlerin etkisinde kaldıkları göz ardı edilmemelidir (Gutman,1982). Tüketicilerin satın alma davranışlarını etkileyen önemli değerlerden biri de tüketim değerleri olup tüketicilerin belirli bir ürünü satın alma, almama, bir ürünü diğerine tercih etme ve belirli bir markayı seçme nedenlerini açıklamaktadır (Sheth vd., 1991b). Örneğin, bir tüketici için bir otomobilin dış görünüşü otomobili satın alma nedeni iken başka bir tüketici için otomobilin yakıt tasarrufu sağlaması satın alma nedenidir (Sheth,1991a). Bu nedenle tüketicilerin ürün özelliklerini değerlendirirken tüketim değerlerinin de etkisinde kaldıkları dikkate alınmalıdır.

Çevreyi koruma duyarlılığının arttığı ortamda günümüz işletmelerinin rekabette üstünlük sağlayabilmeleri, çevreci tüketicilerin satın alma davranışlarını incelemeleri, onların 
ihtiyaç ve isteklerini anlamaları ve karşılamaları ile mümkündür. Bu nedenle diğer tüketicilerden farklı olan çevreci tüketici profillerini incelemek son derece önem taşımaktadır. Dolayısıyla bu çalışmada çevreci kadın tüketicilerin tüketim ve kişisel değerleri açısından homojen bölümlere ayrılıp ayrılmadıklarını ve bu bölümlerin diğer demografik özellikler itibari ile aralarında farklılık olup olmadığını belirlemek amaçlanmıştır. İki bölümden oluşan bu çalışmanın ilk bölümünde kişisel değerler ve tüketim değerleri ile ilgili teorik bilgiler verilmiştir. İkinci bölümde ise kişisel ve tüketim değerleri açısından kadın tüketicileri alt bölümlere ayırmak için, kadın tüketicilere uygulanan anket çalışmasının sonuçlarına yer verilmiştir. Çevreci tüketimde önemli bir paya sahip oldukları düşüncesinden hareketle, çalışma kadın tüketicilere uygulanmıştır. Böylece çevreci kadın pazarlarını daha alt bölümlere ayırmak, onları daha yakından tanımak ve bu yönüyle literatüre katkı sunmak amaçlanmıştır.

\section{LITERATÜR TARAMASI}

\subsection{Kişisel Değerler}

Kişisel değerleri belirlemek üzere yararlanılan Rokeach Değerler Sistemi, Değerler Listesi ve Schwartz Değerler Sistemi en çok kabul görmüş olanlarıdır. Schwartz Kişisel Değerler Sistemi, kişinin tüm ihtiyaçları dikkate alınarak geliştirildiğinden tüketici davranışlarını açıklamada daha yararlı olduğu öne sürülmektedir. Bu nedenle tüketici davranışlarını açıklamada yararlanılan en önemli değer ölçeklerindendir (Ünal vd., 2008: 215). Ayrıca tüketim değerleri ile ilişkili olduğu gerekçesiyle de çevreci tüketim araştırmalarında daha fazla yararlanılmaktadır. Bu değerler sistemine göre kişisel değerlerin iki temel boyutu bulunmaktadır. Bu boyutlardan biri, değişime açıklıkmuhafazakârlık ve diğeri, takdir ve saygı görme-kendini aşmadır. Kendini yönlendirme, uyarılım, hedonizm, güvenlik, uyumluluk ve geleneksellik değerleri değişime açıklıkmuhafazakârlık boyutunda yer alırken; güç, başarı, hedonizm evrensellik, yardımseverlik değerleri ise takdir ve saygı görme (öz- genişletim)-kendini aşma (öz-aşkınlık) boyutunda yer almaktadır (Bilsky ve Schwartz, 1994:167).

Daha önce yapılan bazı araştırmalarda Schwartz'ın "Öz-genişletim” ve “Öz-aşkınlık” değer boyutları ile çevre dostu davranış arasında anlamlı istatistiksel ilişki olduğu (Gruner ve Juhl, 1995; Karp, 1996; Stern vd., 1999; Schultz ve Zelezny, 1999; Schultz vd., 2005; Leiserowitz vd., 2006); bazı araştırmalarda evrensellik ve yardımseverlik değerlerinin (Krystallis ve Chryssohoidis, 2005; Mueller, 2011); bazılarında başarı, güç ve hedonizim değerlerinin çevreci tüketim ile daha fazla ilişkili olduğu (Schultz ve Zelezny, 1999; Schultz vd., 2005; Şener ve Hazer, 2007) tespit edilmiştir. Ayrıca bazı yazarlara göre muhafazakârlık değerine sahip tüketiciler bir şey norm haline gelmedikçe yaşamlarına dâhil etmezler (Follows ve Jobers, 2000: 729). Dolayısıyla bu değerin çevreci tüketim ile ilişkisinin zayıf olduğu öne sürülmektedir (Schultz vd., 2005: 457). Değişime açıklıkmuhafazakârlık boyutunda bulunan kendini yönlendirme ve uyarılım değerlerinin de doğrudan çevresel tutumlarla ilişkisi olmadığı öne sürülmektedir (Thogersen ve GrunertBeckmann, 1997). Dolayısıyla çalışmada, öz-genişletim ve öz-aşkınlık değerleri kullanılmıştır. Öz-genişletim değerleri, insanların kendi kişisel ilgilerini geliştirmeye yönelik iken, öz-aşkınlık değerleri, diğer insanların refahını sağlamaya yöneliktir. Öz- 
genişletim boyutunda yer alan güç değeri sosyal statü ve saygınlık elde etme isteğini ifade etmektedir. Başarı değeri ise kişisel yeterliliğge sahip olmaktır. Öz-aşkınlık boyutunda yer alan iyilikseverlik, çevredeki insanların refahı amaçlarken, evrenselcilik, tüm insanların ve doğanın refahının sağlanmasına hedefler (Schwartz, 1992).

\subsection{Tüketim Değerleri}

Tüketim değerleri teorisi de farklı şekillerde ortaya konulmuştur (Sweeney ve Soutar, 2001; Lin ve Huang, 2012). Bu teori tüketicinin herhangi bir ürün ya da markayı neden tercih ettiklerini daha ayrıntılı ortaya koymaktadır. Bu değerler temel olarak fonksiyonel, epistemik, durumsal, duygusal ve sosyal olmak üzere 5 gruba ayrılmaktadır. Ancak fonksiyonel değerler fiyat ve kalite ölçüt alınarak fonksiyonel kalite ve fonksiyonel fiyat değeri şeklinde ele alınmıştır (Lin ve Huang, 2012: 14).

Fonksiyonel değere göre ürün tercihi yapan tüketici güvenilirlik, dayanıklılık, kalite, ürün içeriği, üretim teknolojisi, geri dönüştürülebilir ambalajın olması ve fiyat gibi niteliklere dikkat etmektedir (Sheth vd., 1991b:160). Duygusal değer, tüketim tercihlerinde "bağlılık, nostalji, heyecan, korku, suçluluk, kızgınlık" gibi duyguların etkili olması ile ortaya çıkmaktadır (Sheth vd.,1991a). K1sacas1, ürünün tüketicide uyandırdıkları duygulardan dolayı tercih edilmesine yol açan bir değerdir (Xiao ve Kim, 2009:612). Sosyal değere göre ürün tercihi yapan tüketiciler, sosyal çevre, referans grubu ve tanıdık görüşünü fayda ölçüsü olarak kabul etmektedirler. Başka bir deyişle sosyal değer, tüketicinin örnek aldığı kişilerin yapılan alımlarla ilgili olumlu veya olumsuz değerlendirme yapmaları ile anlam kazanmaktadır (Sheth, vd. 1991b: 161). Epistemik değer, kişinin arzu ettiği yeniliği aramasını ifade etmektedir. Bu değere göre, tüketici yeni tecrübeler kazanmayı temel almakta ve kendisine yeni bir değer ve tecrübe kazandıracağına inandığı ürünü seçmektedir (Lin ve Huang, 2012: 13). Başka bir deyişle, bu değer bir ürünün taşıdığı yeni ve yaratıcı unsurlar ve tüketicilerin keşfetme ihtiyaçlarına yönelik tatminlerin bütününü içermektedir (Sheth vd.,1991a). Tüketicinin yeniliği araması teknolojik ya da sembolik anlamda da olabilir. Satın aldığı ürünün tüketiciye kazandıracağı imaj sembolik bir değer iken, teknolojideki ilerleme teknolojik değerdir (Dobre vd., 2009: 22). Tüketicinin mevcut markasından sıkılması ve yeni markaları merak etmesi gibi nedenler de epistemik değer olarak ifade edilebilir (Sheth vd., 1991a: 62). Durumsal değer, ürün tercihi yaparken belirli bir koşula göre algılanan faydadır. Örneğin bazı ürünler sadece acil durumlarda kullanılırlar (ambulans) ve bazıları sadece bir kez (düğün, kefen) düşünülürler (Sheth vd., 1991b:162).

Son yıllarda çevreci tüketim ile kişisel değerler arasındaki ilişkiyi ortaya koyan araştırmaların sayısı artmaktadır (Schultz ve Zelezny, 1999). Kişisel değerler ile çevreci satın alma davranışı arasındaki ilişkiyi araştıran çalışmalara göre çevre dostu kişilerin evrenselcilik ve iyilikseverlik değerlerine verdikleri önem yüksek iken, güç ve başarı değerlerine verdikleri önem düşüktür (Schultz vd., 2005; Leiserowitz vd., 2006; Karalar ve Kiracı, 2010; Alnıaçık ve Yılmaz, 2010). Şener ve Hazer (2007), kadın tüketicilerin kişisel değerleri ile çevreci satın alma davranışları arasındaki ilişkiyi araştırmışlardır. Sonuçlara göre kadınların "evrenselcilik ve iyilikseverlik" değer tiplerine diğer değer tiplerine göre daha fazla önem verdikleri görülmüştür. Hedlund (2011), turistlerin değerleri ile ekolojik turizm davranışı arasındaki ilişkiyi araştırmış ve kişisel değerlerin 
sürdürülebilir davranışlar ile ilişkili olduğunu saptamışıtır. Organik gıda satın alma davranışı ile kişisel değerler arasındaki ilişki açısından yapılan çalışmalara göre evrensellik değer tiplerinin organik gıda satın alma davranışı ile pozitif ilişkili olduğu; güç değer tipi ile negatif ilişkili olduğu görülmüştür (Mueller, 2011). Lin ve Huang (2012), tüketicilerin çevreye duyarlılıklarını tüketim değerleri ile karşılaştırmışlardır. Çevre duyarlılığı yüksek olan tüketicilerin çevre dostu ürün satın almaları ile tüketim değerleri arasında iliş̧i olduğu görülmüştür. Candan ve Yıldırım (2013), çevreci tüketim değerleri ile kişisel değerler arasındaki ilişkiyi incelemiş ve aralarında anlamlı pozitif ilişkinin olduğunu tespit etmişlerdir. Suki ve Suki (2015), tüketim değerlerinin çevresel kaygı üzerindeki etkisini araştırmış ve çevresel kaygıda fonksiyonel, sosyal ve yaratıcılık değerlerinin en etkili değerler olduğunu tespit etmişlerdir. Bazı araştırmacılara göre değer yanı sıra demografik özellikler de önemli bir değişkendir. Dietz vd. (2002) ve Mostafa (2007), cinsiyet, değer ve çevrecilik arasındaki ilişkiyi araştırmış ve bunlar değişkenler arasında anlamlı ilişkiler olduğunu saptamışlardır. Gilg vd. (2005), üst yaş grubundaki iyi eğitimli ve gelirli olan kadın bireylerin daha çevreci olduklarını tespit etmişlerdir. Işıldar (2008) ise, cinsiyetin çevreci davranışlar üzerinde etkili bir değişken olmadığını saptamıştır. Demirel vd. (2009), rekreasyonel aktivitelere katılımın çevreye yönelik tutum üzerindeki etkisini değerlendirmişlerdir. Araştırma sonucunda çevreye yönelik tutumların yaş gruplarına göre farklılık gösterdiği ancak cinsiyete göre farklılık göstermediği tespit edilmiştir. Sam vd. (2010), kadınların erkeklerden daha çevreci olduklarını tespit etmişlerdir. Özdemir (2013), sürdürülebilir tüketim davranışlarında kişisel değerlerin eğitimli kadınların giysi elden çıkarma davranışları üzerindeki etkisine yönelik bir araştırma yapmıştır. Araştırma sonucuna göre kadınların iyilikseverlik ve evrenselcilik değer tiplerine, güç-başarı ve hedonizm değer tiplerine göre daha fazla önem verdikleri ve daha çevreci davrandıkları görülmektedir. Yıldırım ve Candan (2015), tüketim ve kişisel değerler açısından çevreci tüketicilerin öz-aşkın fonksiyonel çevreciler ve özgelişmiş sosyal çevreciler olmak üzere iki kümeye ayrıldıklarını belirlemişlerdir. Ayrıca demografik özellikler açısından da bu kümeler arasında anlamlı farklar olduğunu belirlemişlerdir.

Literatürde çevreci tüketim konusunda yapılan çok fazla çalışma olmasına rağmen kişisel değerler, tüketim değerleri ve demografik özellikleri bir arada ele alan çalışmaların sayısı oldukça sınırıdır (Candan ve Yıldırım, 2013; Yıldırım ve Candan, 2015). Ayrıca kadın tüketicilerin çevresel alımlarda çok etkin bir rol oynadıkları çalışmalarda çok fazla vurgulanmasına rağmen, kadın tüketicileri daha yakından tanımak amacına yönelik çalışmaların sayısı yok denecek kadar azdır (Şener ve Hazer, 2007). Bu değişkenleri bir arada ele alan kadınlara yönelik özellikle Doğu Anadolu Bölgesi'nde yapılmış herhangi bir çalışmaya rastlanmamıştır. Bu yönüyle çalışmanın çevre dostu ürün satın alan kadın tüketici pazarına dair ayrıntılı bilgi sunmasına yardımcı olması beklenmektedir. Ayrıca Ay ve Ecevit (2005)'in psikografik değişkenlerin çevreci tüketim davranışlarını belirlemede demografik değişkenlere göre daha etkili olduğunu öne sürmesi de bu değişkenler açısından bir çalışmanın yapılmasını gerektirmiştir. 


\section{ARAŞTIRMANIN METODOLOJISİ}

\section{1. Örnekleme ve Veri Toplama Süreci}

Kadınların çevreci tüketim konusunda erkeklerden daha çevreci oldukları sürekli öne sürülmesine rağmen kadınlara yönelik yapılan çalışmalar yok denecek kadar azdır (Şener ve Hazer, 2007). Literatürdeki boşluk dikkate alınarak çalışma kapsamına çevreci kadın tüketiciler dahil edilmiştir. $\mathrm{Bu}$ araştırmanın ana kütlesi, Muş il merkezinde yaşayan çevreci kadın tüketicilerden oluşmaktadır. Ana kütlenin tamamına ulaşmak, zaman ve maliyet kısıtlarından ötürü mümkün görülmemiştir. Dolayısıyla örnek büyüklüguünün minimum 384 olmasına karar verilmiştir (Kurtuluş, 2010: 67). Heterojen bir örnekleme ulaşmak amacıyla Haziran-Ağustos 2016 tarihinde 421 kişilik bir katılımcı üzerinden yüz yüze anket yöntemi ile veriler toplanmıştır. Bu kişiler kolayda örnekleme yöntemi ile seçilmiştir. Toplanan veri incelendiğinde, 391 kişiden elde edilen verilerin analizler için uygun olduğu belirlenmiştir. Anket 2 grup sorudan oluşmaktadır. Birinci grup kişisel ve tüketim değerlerine yönelik sorulardan oluşmakta ve ikinci grup demografik özellikleri ölçmektedir.

Davranışın değerle olan ilişkisi incelendiğinde tüm değer tiplerinin kullanımının pratik ve kullanışlı bir yol olmadığı öne sürülmektedir (Stern vd., 1998; Stern ve Dietz,1994; Karp, 1996). Bazı araştırmalarda genellikle Schwartz'ın Değer Listesinin tamamı yerine araştırmanın ihtiyacına yönelik olacak şekilde kısaltılmış değer listesinin kullanımı uygun görülmektedir (Thogersen ve Ölander, 2002). Bu durum dikkate alınarak çalışmada, Lindeman ve Verkasalo (2005) tarafından revize edilen Schwartz'ın kısaltılmış kişisel değerler listesindeki 23 ifadeden oluşan öz-aşkınlık ve öz-genişletim değerlerinden yararlanılmıştır. Tüketim değerleri ise 23 ifadeden oluşan Lin ve Huang 2012 ölçeğinden yararlanılarak ölçülmüştür. Kişisel değerler 6'li likert (1: kesinlikle katılmıyorum, 6: tamamen katılıyorum); tüketim değerleri ise 5'li likert (1: kesinlikle katılmıyorum, 5: tamamen katılıyorum) ölçeğinde hazırlanmıştır. Veriler SPSS 20,0 istatistik programı ile analiz edilmiş, tanımlayıcı istatistik, faktör, kümeleme ve diskriminant analizleri uygulanmıştır.

\subsection{Araştırmanın Modeli ve Hipotezleri}

Araştırmanın amacı doğrultusunda kurulan model ve hipotezler aşağıdaki gibi gösterilmiştir.

H1: Çevreci kadın tüketiciler, tüketim değerleri ve kişisel değerler açısından homojen alt gruplara ayrilabilirler.

H2: Çevreci kadın tüketicilerin demografik özellikleri açısından kişisel değerleri ve tüketim değerleri arasında anlamlı farklılık vardır.

H2a: Çevreci kadın tüketicilerin yaşları açısından değerleri arasında anlamlı farklılık,

H2b: Çevreci kadın tüketicilerin meslekleri açısından değerleri arasında anlamlı farklılık,

H2c: Çevreci kadın tüketicilerin gelirleri açısından değerleri arasında anlamlı farklılık, 
H2d: Çevreci kadın tüketicilerin eğitim durumları açısından değerleri arasında anlamlı farklılıklar vardır.

H2e: Çevreci kadın tüketicilerin medeni halleri açısından değerleri arasında anlamlı farklılıklar vardır.

Şekil 1. Araştırma Modeli

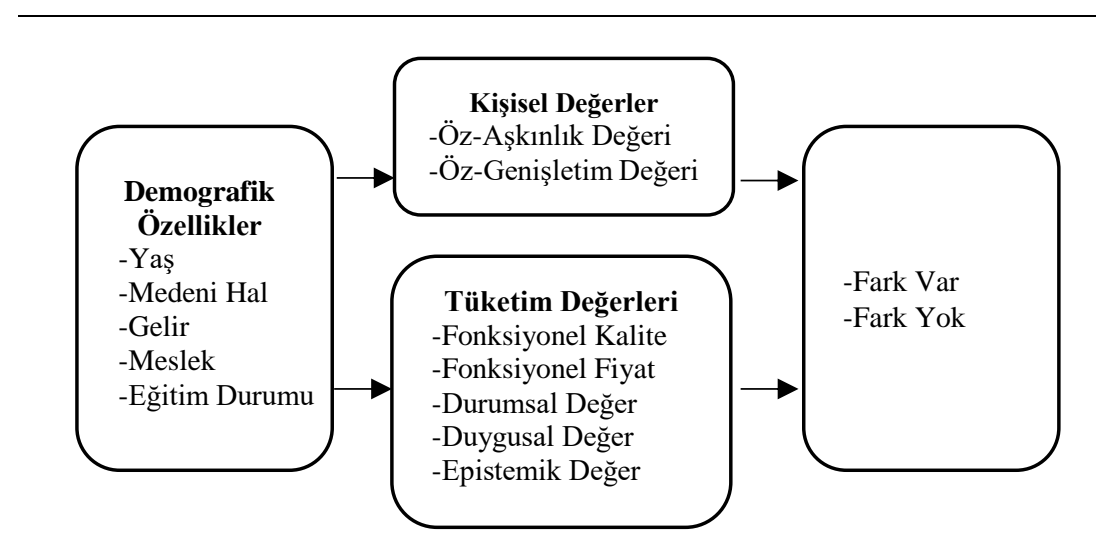

\section{ARAŞTIRMA VERILERININ ANALIZI}

\subsection{Araştırma Örneğinin Özellikleri}

Katılımcıların demografik özellikleri Tablo1'de gösterilmiştir.

Tablo 1. Demografik Özellikler

\begin{tabular}{|c|c|c|c|c|c|c|c|c|}
\hline $\begin{array}{l}\Xi \\
\text { 渮 } \\
\text { 壬 }\end{array}$ & 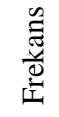 & do & $\frac{\Xi}{0}$ & 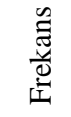 & $b^{2}$ & $\frac{\frac{y}{0}}{\frac{0}{v}}$ & 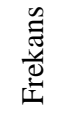 & $b^{0}$ \\
\hline Orta öğrenim & 71 & 18.2 & $<1300 \mathrm{TL}$ & 59 & 15.1 & Öğrenci & 49 & 12.5 \\
\hline Lise & 95 & 24.3 & $1300-2300$ & 80 & 20.5 & Memur & 153 & 39.1 \\
\hline Lisans & 138 & 35.3 & $2301-3300$ & 102 & 26.1 & Özel sektör & 63 & 16.1 \\
\hline Lisansüstü & 87 & 22.3 & $4301-5300$ & 79 & 20.2 & Emekli & 24 & 6.1 \\
\hline Toplam & 391 & 100 & $>5300 \mathrm{TL}$ & 71 & 18.2 & Diğer & 102 & 26.1 \\
\hline 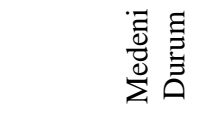 & & 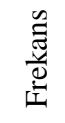 & $b^{\circ}$ & \multicolumn{2}{|c|}{$\stackrel{\pi}{\sim}$} & 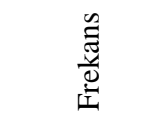 & \multicolumn{2}{|c|}{$\sigma^{\circ}$} \\
\hline Bekar & & 136 & 34.8 & \multicolumn{2}{|c|}{$18-35$} & 199 & \multicolumn{2}{|c|}{50.9} \\
\hline Evli & & 255 & 65.2 & \multicolumn{2}{|l|}{$36+$} & 192 & \multicolumn{2}{|c|}{49.1} \\
\hline Toplam & & 391 & 100 & \multicolumn{2}{|c|}{ Toplam } & 391 & \multicolumn{2}{|c|}{100} \\
\hline
\end{tabular}


Tablo 2. Kadınların Çevreci Tüketim Yapmaya Dikkate Ettikleri Ürün Grupları

\begin{tabular}{lcc}
\hline Ürün Grupları & Frekans & $\%$ \\
\hline Kozmetik & 62 & 15.9 \\
Gida (organik) & 113 & 28.9 \\
Evsel temizlik & 75 & 19.2 \\
Giyim & 56 & 14.3 \\
Mutfak araç gereçleri & 33 & 8.4 \\
Elektronik eşyalar & 34 & 8.7 \\
Mobilya & 18 & 4.6 \\
Toplam & 391 & 100 \\
\hline
\end{tabular}

Tablo 2'de görüldüğü gibi katılımcıların büyük çoğunluğunun $(\% 28,9)$ gıda ürünlerinde çevreci davranmaya önem verdikleri ve en az ise mobilya ürünlerinde çevreci tüketime dikkate ettikleri görülmektedir $(\% 4,6)$.

\subsection{Faktör Analizinin Sonuçları}

\subsubsection{Katılımcıların Kişisel ve Tüketim Değerleri}

Kişisel ve tüketim değerlerinin kaç faktörde toplandığını belirlemek amacı ile sırası ile değişkenlere açıklayıcı faktör analizi yapılmıştır. Analiz sonucu öz değeri 1 'den büyük 2 faktör elde edilmiş ve değişkenlerin 0.40 ve üzeri faktör yüklerine sahip olanlar dikkate alınmıştır. Analiz sonucunda kişisel değer faktörleri toplam varyansın \%40,47'ünü açıklamaktadır (KMO örneklem yeterlilik ölçütü: \%77,4 Barlett Küresellik testi: 4618.021, $\mathrm{p}<0,000)$. Tüketim değeri değişkenlerine uygulanan faktör analizi sonucunda öz değeri 1'den büyük 6 faktör elde edilmiştir. Bu faktörler toplam varyansın \%69,43'sını açıklamaktadır (KMO örneklem yeterlilik ölçütü: \%80,3 Barlett Küresellik testi: 4519.098, p<0.000). Tablo 3'de ve Tablo 4'de değerlere ait faktör yükleri, varyans yüzdeleri ve öz değerleri gösterilmiştir.

Tablo 3. Kişisel Değerler

\begin{tabular}{lc}
\hline Öz-Gelişmişlik & Faktör Yükleri \\
\hline Sosyal güç & 0.657 \\
Otorite & 0.671 \\
Zenginlik & 0.619 \\
Başarı & 0.580 \\
Yetenekli & 0.569 \\
Etkili & 0.664 \\
Hirslı & 0.542 \\
Neşeli & 0.443 \\
Kendini Şımartan & 0.530 \\
Haz & 0.593 \\
\hline Varyans Yüzdesi: 24.556 & Güvenirlik: 79.2 \\
\hline Öz-Aşkınlık & \\
\hline Barış içinde dünya & 0.632 \\
Doğa bütünlüğü & 0.683 \\
Güzel dünya & 0.747 \\
Eşitlik & 0.652
\end{tabular}




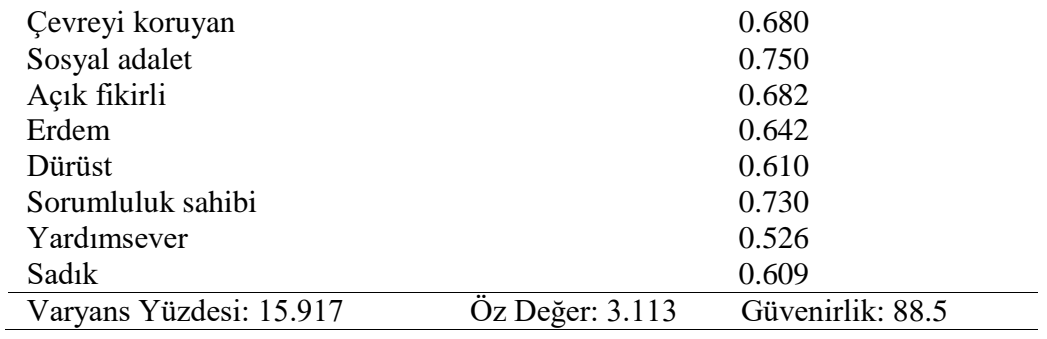

Araştırma sonucunda, 22 alt değerden oluşan 2 faktör elde edilmiştir. Birinci faktörde öz gelişmişlik boyutuna ait tüm değişkenler yer almıştır. İkinci faktörde affedici değişkeni dışında öz-aşkınlık boyutuna ait değişkenlerin hepsi yer almıştır.

Tablo 4. Tüketim Değerleri

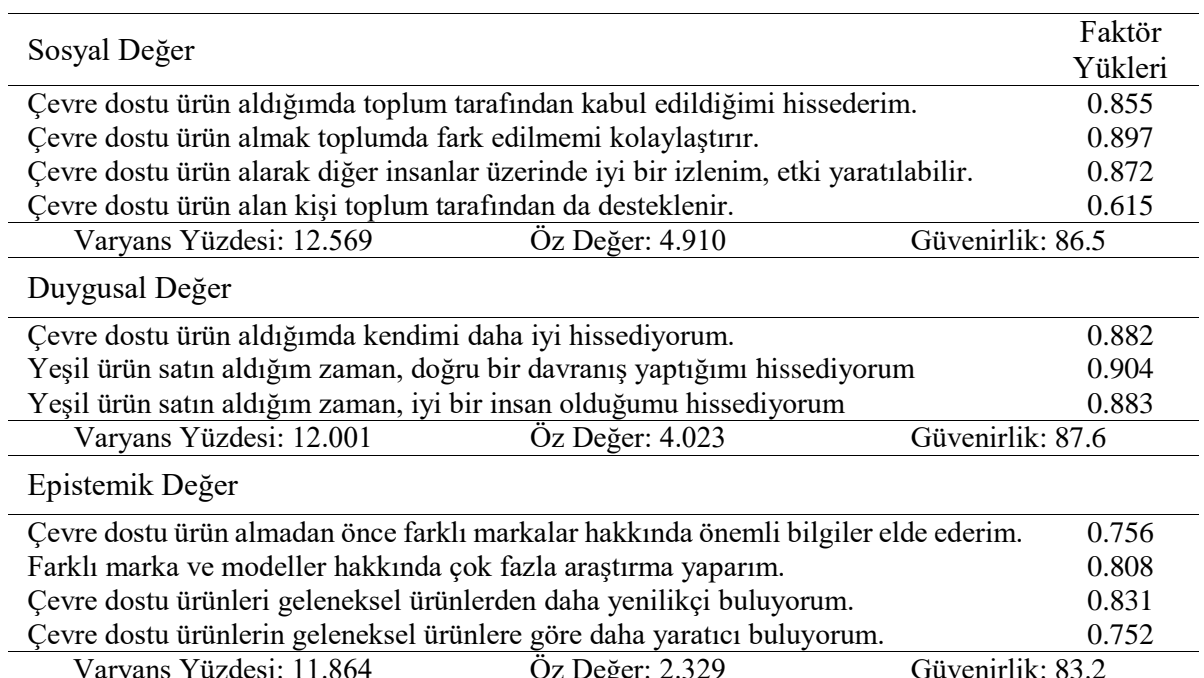

Fonksiyonel-Kalite

Çevre dostu ürünler tutarlı (kalıcı, istikrarlı) kaliteye sahiptirler.

Çevre dostu ürünler yüksek performansa sahip olmalıdır. Varyans Yüzdesi: 11.767

Öz Değer: 1.857 Güvenirlik: 85.3

Fonksiyonel-Fiyat

Uygun fiyatlı olmalıdır.

Yeşil ürünler, harcadığım paradan fazlasını sunmaktadır.

Fiyatına göre iyi ürünlerdir.

Geleneksel ürünlere göre daha ekonomik olmalıdır.

Varyans Yüzdesi: 10.711

Öz Değer: 1.493

0.810

Durumsal Değer

Kötüleşen hava koşullarından dolayı geleneksel ürün yerine çevreci ürünleri tercih ederim. 
Çevreci ürün tüketimini destekleyen devlet yardımları olursa, geleneksel ürün yerine $\quad 0.819$ çevreci ürün alırım.

$\begin{array}{ll}\text { Sadece çevreci ürünlere yönelik bir satış indirimi varsa, yeşil ürün satın alırım. } & 0.706\end{array}$

$\begin{array}{ll}\text { Yeşil ürünleri her yerde bulabilirsem, geleneksel ürün almak yerine onları alırım. } & 0.637\end{array}$

Varyans Yüzdesi: $10.523 \quad$ Öz Değer: 1.358 $\quad$ Güvenirlik: 82.0

\subsection{Katılımcıların Tüketim Değerleri ve Kişisel Değerler Açısından Alt Gruplara Ayr1mas1}

Katılımcıları değerlerine göre gruplara ayırmada kümeleme analizi yapılmıştır. Küme sayısını belirlemek için hiyerarşik kümeleme analizi yapılmıştır. Yığılım katsayılarındaki yüzde artış incelenmiş ve 2 ile 3 küme belirlemenin doğru olacağı görülmüştür. İkinci aşamada elde edilen küme sayıları K-Ortalamalar yöntemi ile analize tabi tutulmuş ve küme sayısı 2 olarak belirlenmiştir. Tablo 5'te elde edilen kümelerde toplanan katılımcı sayıları gösterilmiştir.

Tablo 5. Kümelerin İçerdiği Toplam Sayı

\begin{tabular}{lcc}
\hline Kümeler & Say1 & Yüzde \\
\hline 1 & 185 & 0.47 \\
2 & 194 & 0.50 \\
Kayıp Değer & 12 & 0,03 \\
Toplam & 379 & 100 \\
\hline
\end{tabular}

Tablo 5'te görüldüğü gibi, 1. kümede 185 ve 2. kümede 194 katılımcı bulunmaktadır. Ayrıca çalışmada 12 kaybolan veri bulunmaktadır. Kişisel ve tüketim değerleri itibari ile iki küme arasında anlamlı farklılıkların tespit edilmesi için anova analizi uygulanmıştır. Tablo 6'da annova analizi ve kümeleri ayırmada anlamlı olan değişkenlerin ortalama değerleri gösterilmiştir.

Tablo 6. Kümelerin Ortalama Değerleri

\begin{tabular}{lccrc}
\hline \multicolumn{1}{l}{ Kümeler } & $\begin{array}{c}\text { 1.Küme } \\
\text { Değişkenler }\end{array}$ & $\begin{array}{c}\text { 2.Küme } \\
\text { (Ort.) }\end{array}$ & F değeri & P değeri \\
\hline Tüketim Değerleri & & & & \\
\hline Sosyal Değer & 3.07 & 3.95 & 122.049 & 0.000 \\
Epistemik Değer & 2.16 & 3.98 & 727.237 & 0.000 \\
Duygusal Değer & 3.19 & 2.48 & 38.207 & 0.000 \\
Fonksiyonel-Fiyat Değeri & 3.90 & 3.72 & 5.499 & 0.020 \\
Fonksiyonel-Kalite Değeri & 3.37 & 3.02 & 14.316 & 0.000 \\
Durumsal Değer & 3.70 & 3.41 & 13.863 & 0.000 \\
\hline Kişisel Değerler & & & & \\
\hline Öz-Gelişmişlik & 4.31 & 4.50 & 4.505 & 0.034 \\
Öz-Aşkınlık & 5.48 & 5.23 & 10.700 & 0.001 \\
\hline
\end{tabular}

Tablo 6'a göre tüm değerler $\% 5$ önem düzeyinde istatistiki yönden anlamlı olup çevreci tüketiciler, her iki değer açısından homojen alt gruplara ayrılabilirler. Elde edilen kümelerin özellikleri aşağıda verilmiştir. 
(i) Küme: Öz-aşkın fonksiyoneliler: Bu kümede yer alan tüketiciler öz-aşkın kişisel değerine sahiptirler. Bu kişilerde evrensel düşünce ve yardımseverlik özellikleri baskındır. Bu kişiler yardım etmeyi seven, sorumluluk sahibi, dürüst ve sadık insanlardır. Çevresindeki insanların mutluluğuna önem verdikleri için barış içinde yaşamak, çevreyi korumak ve doğa bütünlüğünü sağlamak isterler. Bu kişilerin çevreci ürün tercihlerinde fonksiyonel, durumsal ve duygusal tüketim değerleri etkili olmaktadır. Fonksiyonel değerlere göre alım kararı verirken hem fiyatına hem de kalitesine odaklanmaktadırlar. Duygusal değerleri baskın olan bireyler kendilerini iyi hissettikleri için çevreci tüketim yaptıklarını öne sürerler. Başka bir deyişle onlara göre gerçekten iyi insan olmanın yolu çevreci ürünleri almaktır. Kötüleşen hava koşulları, artan devlet yardımları, satış indirimleri ve çevreci ürünlerin bulunabilirliği gibi durumlar onları çevreci tüketime yönlendiren durumsal değerleridir.

(ii) Küme: Öz-gelişmiş yaratıcılar: Bu grupta yer alan tüketiciler öz-gelişmişlik kişisel değerine sahiptirler. Onlar için başarı, güç ve hedonizm ön plandadır. Otorite, sosyal güç ve zenginliği güç kaynağı olarak görmektedirler. Başarıya önem veren neşeli bireylerdir. Çevreci ürün tüketimi ile başarılarının, güçlerinin ve hedonizm duygularının artacağını düşünmektedirler. Tüketim değerlerinden sosyal ve yaratıcılık değerleri ön plana çıkmaktadır. Dolayısıyla çevre dostu ürünleri alarak toplum tarafından kabul edilirliklerinin artacağını düşünmektedirler. Ayrıca çevre dostu ürünlerin yaratıcı özelliklere sahip olduğunu düşünerek de almaktadırlar. Kısacası bu tüketici grubu kendisine yeni bir değer, tecrübe kazandırdığına inandığı ve sosyal kabulünü arttırdığını düşündüğü ürünü almaktadır.

\subsection{Katılımcıların Demografik Özellikleri İtibari ile Değerleri Arasındaki Farkl111kların İncelenmesi}

Kadın tüketicilerin demografik özelliklerine göre değerleri arasındaki farklılı̆̆ı görmek amacı ile aşamalı ayırma analizi yapılmıştır. Demografik değişken, kriter değişkenini ve değerler ise tahmin değişkenini oluşturmuştur. Yapılan analiz sonucunda demografik değişkenlerden sadece yaş kadın tüketicileri değerleri açısından ayırmada anlamlı çıkmıştır. Bu nedenle sadece yaş değişkeni açısından elde edilen Wilk's Lambda Değerleri ile Öz Değerler Tablo 7'de gösterilmiştir.

Tablo 7. Kanonik Ayırma Fonksiyonu, Wilk’s Lambda Değerleri ve Öz Değerler

\begin{tabular}{lcccc}
\hline Fonksiyon & Öz- Değer & Varyans\% & Kümülâtif \% & $\begin{array}{c}\text { Kanonikal } \\
\text { Korelâsyon }\end{array}$ \\
\hline 1 & $0.085(\mathrm{a})$ & 100.0 & 100.0 & 0.280 \\
\hline Fonksiyonların Testi & $\begin{array}{c}\text { Wilks’ } \\
\text { Lambda }\end{array}$ & Ki-Kare & df & $\begin{array}{c}\text { Anlamll1kk } \\
\text { Düzeyi }\end{array}$ \\
\hline 1 & 0.922 & 30.408 & 8 & 0.000 \\
\hline
\end{tabular}

Tablo 7'de görüldüğü gibi, kanonik ayırma fonksiyonları, toplam varyansın \%100'ünü açıklamaktadır. Kanonik korelâsyona bakıldığında, fonksiyonun kanonik korelâsyonu 0.280'dir. Wilk's Lambda değeri 0.000 anlamlılık düzeyinde 0.922'dir. Bu fonksiyonun değeri istatistikî bakımdan anlamlıdır. Tablo 8' de Yapı Matrisi yer almaktadır. 
Tablo 8: Yap1 Matrisi

\begin{tabular}{lc}
\hline & Fonksiyon \\
\hline Değişkenler & 1 \\
\hline Duygusal Değer & 0.625 \\
Fonksiyonel Kalite Değeri & -0.572 \\
Öz-Gelişmişlik Değeri & 0.444 \\
Sosyal Değer & -0.171 \\
Epistemik Değer & -0.116 \\
Öz-Aşkınlık Değeri & -0.066 \\
Durumsal Değer & 0.049 \\
Fonksiyonel Fiyat Değeri & 0.017 \\
\hline
\end{tabular}

Tablo 8'de değişkenlerin mutlak değerleri itibariyle hangisinin en iyi şekilde ayırıcı özelliğe sahip olduğu gösterilmektedir. Görüldüğü gibi duygusal değer, fonksiyonel kalite ve öz aşkınlık değişkenleri iyi ayırma gücüne sahiptirler. Bu değişkenlerden hangilerinin istatistikî anlamda ayırmada önemli olup olmadıklarının belirlenmesi için Wilks' Lambda'sı F testi ile kontrol edilmiş ve sonuçlar Tablo 9'da gösterilmiştir.

Tablo 9. Grup Ortalamaları Eşitliği Testi

\begin{tabular}{lccccc}
\hline Değişkenler & Wilks' Lambda & $\mathrm{F}$ & $\mathrm{df}_{1}$ & $\mathrm{df}_{2}$ & Sig. \\
\hline Sosyal Değer & 0.998 & 0.941 & 1 & 377 & 0.333 \\
Epistemik Değer & 0.999 & 0.433 & 1 & 377 & 0.511 \\
Duygusal Değer & 0.968 & 12.497 & 1 & 377 & 0.000 \\
Fonksiyonel Fiyat Değeri & 1.000 & 0.010 & 1 & 377 & 0.922 \\
Fonksiyonel Kalite Değeri & 0.973 & 10.484 & 1 & 377 & 0.001 \\
Durumsal Değer & 1.000 & 0.077 & 1 & 377 & 0.781 \\
Öz-Genişletim Değeri & 1.000 & 0.140 & 1 & 377 & 0.709 \\
Öz-Aşkınlık Değeri & 0.984 & 6.324 & 1 & 377 & 0.012 \\
\hline
\end{tabular}

Tablo 9'da görüldüğü gibi, duygusal değer, fonksiyonel kalite ve öz-aşkınlık değeri 0.01 anlamlılık düzeyinde iyi bir ayırma gücüne sahiptir. Tablo 10'da anlamlı çıkan değişkenlerin grup ortalamaları verilmiştir.

Tablo 10. Grup Ortalamaları Eşitliği Testi

\begin{tabular}{lcc}
\hline Değişkenler & Genç & Yaşlı \\
\hline Duygusal değer & 2.62 & 3.04 \\
Fonksiyonel kalite & 3.34 & 3.04 \\
Öz-aşkınlık & 5.26 & 5.44 \\
\hline
\end{tabular}

Tablo 10'daki ortalamalara göre, genç kadın tüketicilerin çevreci ürün satın almada daha çok fonksiyonel değere (kalite, ambalaj, içerik vb.) önem verdiklerini; orta ve üst yaş grubundakilerin ise üründe daha çok duygusal değerlere önem verdiklerini ve evrensel davrandıklarını görmekteyiz. Tablo 11 'de sınıflandırma sonuçları gösterilmiştir. 
Tablo 11. Sınıflandırma Sonuçları

\begin{tabular}{lccc}
\hline \multirow{2}{*}{ Yaş } & \multicolumn{2}{c}{ Tahmini Grup Üyeliği } & \multirow{2}{*}{ Toplam } \\
\cline { 2 - 3 } & Genç & Yaşlı & \\
\hline Genç & 124 & 75 & 199 \\
Yaşlı & 80 & 112 & 192 \\
\hline Toplam & 204 & 187 & 391 \\
\hline Genç (\%) & 62.3 & 37.7 & 100 \\
Yaşl1 (\%) & 41.7 & 58.3 & 100 \\
\hline
\end{tabular}

Doğru sınıflandırma oranı : \%60.4

Tablo 11'de görüldüğü gibi doğru sınıflandırma oranı \%60,4'dür. Bu durumda, ayırma fonksiyonlarının test örneğine uygulanmasıyla elde edilen sınıflandırma oranının tesadüfî sinıflandırmadan elde edilecek doğru sınıflandırma oranından istatistiksel olarak büyük olup olmadığını test etmek gerekir (Kurtuluş, 1998: 477). Bu amaçla yararlanılan Morrison şans modeline göre $\mathrm{P}$ (doğru) $=0.491$ olduğu tespit edilmiştir. Ayırma fonksiyonundan elde edilen 0.604 oranının Morrison şans modelinden elde edilen 0.491 oranından istatistiksel açıdan büyük olup olmadığ $1 \% 5$ önem derecesinde $\mathrm{Z}$ testi ile test edilmiş ve $Z$ değeri 4.520 olarak bulunmuştur. Buna göre hesaplanan $Z$ değeri, teorik $Z$ değerinden (1.96) çok daha büyüktür. Bu sonuçlar diskriminant fonksiyonunun tesadüfî ayırmadan çok daha iyi ayırdığını göstermektedir. $Z$ testi dışında, sınıflandırma matrisinin ayırma gücü ile şans modeli, Press Q istatistiği ile karşılaştırılmıştır. Press Q, doğru sınıflandırma sayısı ile toplam örnek büyüklüğü ve grup sayısının karşılaştırılmasına dayanmaktadır. $\mathrm{Bu}$ karşılaştırma sonucu bulunan değer, kritik değer ile karşılaştırılmaktadır. Hesaplanan değer kritik değerden büyük olduğunda, sınıflandırma matrisinin şans modelinden istatistikî olarak güçlü olduğu söylenebilir (Hair vd.,1998:270). Yapılan hesaplamalar sonucunda; Press Q değerinin 16.780 olduğu ve kritik değerden (\%95 güven aralı̆̆ındaki kritik değer: 3.83) büyük olduğu tespit edilmiştir. Bu sonuca dayanarak, sınıflandırma matrisinin şans modelinden daha iyi ayırdığı söylenebilir. Bu sonuçlar doğrultusunda sadece H2a hipotezi kabul edilmiştir.

\section{SONUÇ}

$\mathrm{Bu}$ çalışmada, kişisel ve tüketim değerleri açısından çevreci kadın tüketicileri alt kümelere ayırmakta ve bunun dışında belirlenen kümelerin demografik özellikleri itibari ile aralarında farklılık olup olmadığı incelenmektedir. Araştırma sonuçları aşağıda verilmiştir:

Ankete katılan katılımcıların büyük çoğunluğu evli, orta ve üst gelir seviyesine sahip, üniversite mezunu ve memur kişilerden oluşmaktadır. Ayrıca çevreci tüketime önem verdikleri ürün grupları sırası ile en çok gıda, evsel temizlik, kozmetik ve giyimdir. Yapılan kümeleme analiz sonucunda, kadın katılımcılar kişisel ve tüketim değerleri açısından iki kümeye ayrılmıştır. Birinci kümede yer alan tüketicilerin öne çıkan kişisel değerleri evrensellik ve yardımseverlik boyutlarını içeren öz-aşmadır. Bu bireylerin çevreci tüketim yapmalarında etkili olan kişisel özellikleri; barış içinde bir dünya, daha güzel bir dünya, çevre koruması, doğanın bütünlüğü, eşitlik ve sosyal adalettir. Ayrıca yardım etmeyi sevdiklerinden başkalarının menfaatlerini de göz ardı etmezler. Bu 
anlamda da çevreci tüketimi bir sorumluluk olarak görmektedirler. Bu kümede yer alan tüketicilerin çevreci davranmalarının altında yatan nedenler; çevreci ürünün kaliteli olduğuna ve çevreci davranarak kendilerini daha mutlu hissedeceklerine inanmalarıdır. Ayrıca bu kümedeki tüketiciler kötüleşen çevre koşulları, çevreci ürün indirimleri ve devlet teşvikleri nedeni ile de çevreci alımlar yapmak isterler. İkinci kümede yer alan tüketiciler öz-gelişmişlik kişisel değerine sahiptirler. Başarıya önem veren neşeli bireylerdir. Çevreci ürün tüketimi ile başarı, güç ve hedonik değerlerinin artıracağını düşünmektedirler. Çevreci tüketim yapmalarının altında yatan en önemli nedenlerden biri, çevreci ürün alarak toplumda onaylanmaktır. Çevreci ürünlerin geleneksel ürünlere göre daha yaratıcı şeyler sunduğuna inandıkları için de çevreci alımlar yaparlar. Belirlenen kümelerin demografik özellikleri itibari ile değerleri arasında anlamlı farklılıkların olup olmadığını belirlemek için ayırma analizi uygulanmıştır. Yapılan analizin sonucunda katılımcıların yaş dışında hiçbir demografik özelliğin kümeleri ayırmada anlamlı bir fark yaratmadığ desteklenmektedir (Gilg vd., 2005: 484). Kadınların yaş düzeyleri açısından aralarındaki farkl1lıklar incelendiğinde, gençlerin daha çok çevreci ürünün kalitesine önem verdikleri, orta ve üst yaş grubundakilerin ise duygusal değerlerinin ürün alımında etkili olduğu görülmüştür. Üst yaş grubundaki kadınlar çevreci ürün alarak kendilerini daha mutlu hissettiklerini ifade etmektedirler. Başka bir deyişle orta yaş ve üzeri yaş grubundaki kadınların doğru bir şey yaptıklarına ve doğayı koruduklarına inandıkları için satın aldıkları görülmüştür. Buna göre katılımcılar arasından yaşı daha büyük olanlar için çevre dostu ürünlerin sahip oldukları duygusal etkenlerin daha önemli olduğu söylenebilir. Ayrıca evrensel düşündüklerinden çevre korumaya gençlerden daha fazla önem vermektedirler. $\mathrm{Bu}$ durum literatürle uygunluk göstermektedir (Devrani, 2010: 55; Özdemir, 2013: 79). Gençlerin kalite değerinin baskın olması, çevre dostu olmasına en çok dikkate ettikleri ürün grubunun gıda olmasından kaynaklanabilir. Çalışmanın sonuçları itibari ile literatüre sağlaması beklenen katkılar aşă̆ıdaki gibidir:

$\mathrm{Bu}$ çalışmanın çevre dostu ürün satın alan kadın tüketicilerin değerlerinin ve demografik özellikler itibari aralarındaki farklılıkların anlaşılmasına, bu pazara dair ayrıntılı bilgi elde edilmesine yardımcı olacağı düşünülmektedir. Kadınlara yönelik uygulanan bu çalışma niş pazar olarak değerlendirilen yeşil pazarın, homojen olan daha özel/alt pazar bölümlerine ayrılabildiğine ve kadınların yeşil tüketim davranışının yaygınlaşmasında önemli bir pazar bölümünü oluşturabildiğine tekrar vurgu yapmaktadır. Çalışmanın işletmelere katkıları aşağıdaki gibidir:

Tüketicilerin çevreci davranmalarının altında yatan kişisel ve çevresel değerlerin anlaşılmasında ve bu değerler doğrultusunda pazarlama stratejilerinin geliştirilmesinde işletmelere faydalı olması beklenmektedir. Tüketicilerin bazılarının belirgin olan kişisel özellikleri, topluma ve çevreye saygıyı ifade eden evrensellik ve yardımseverliktir. Bu kişilere ulaşmada sıcak ilişkilerin vurgulandığ 1 mesajların verilmesi faydalı olacaktır. İşletmeler fiyat ve kalite odaklı tüketiciler için farklı fiyat aralıklarında iyi kalitede çevreci ürünleri geliştirebilir ve bunu duygusal uyaranlarla destekleyebilirler. Tüketiciler çevreci ürünleri alarak daha iyi insan olduklarını hissettiklerinden işletmeler reklamlarda duygusal temalara yer vermelidirler. Örneğin çevre dostu davranmamanın olumsuz sonuçlarına odaklanarak tüketicilerde suçluluk duygusu uyandırılabilir. Böylece çevreci tüketim davranışlarını da teşvik edebilirler. Kötüleşen hava koşulları, artan devlet 
yardımları, artan satış indirimleri ve yeşil ürünlerin bulunabilirliği gibi durumlar, tüketicileri çevreci tüketime yönlendiren durumsal değerlerdir. İşletmeler fonksiyonel ve duygusal değerler yanında bu değerleri de göz önünde bulundurarak çevreci ürünler için indirime odaklanmalı ve çevreci ürün bulunabilirliğine önem vermelidirler. İşletmeler depolarında çevre dostu ürünlerin bulunmasına dikkat etmelidirler. Bazı tüketiciler çevreci ürünlerde yaratıcılık ve sosyallik aramaktadırlar. Firmaların bu tüketici grubuna ulaşabilmeleri için çevreye duyarlı olduklarını gösteren sponsorluklar üstlenmeleri gerekmektedir. $\mathrm{Bu}$ çabalar bu gruptaki tüketicilerin daha çevreci davranmalarını sağlayacaktır. Epistemik (yaratıcılık) değere sahip tüketiciler merak duygusu ile çevreci ürünleri aldıklarından işletmeler sadece yeşil ürünün fonksiyonel değerine değil epistemik değerine de önem vermeli, tüketicinin bilgi ve farkındalıklarını artırmalıdırlar. Promosyonlara ağırlık vererek onların meraklarını uyanık tutmaları gerekmektedir. Ayrıca firmalar tüketicilere yaratıcı ve yeni olan çevre dostu ürünler sunmaları gerekmektedir. İşletmeler genel olarak tüm tüketicileri çevreci davranmaya yönlendirecek konferans, konser, festival gibi çevreci aktivitelere ağırlık vermelidirler.

Kişisel değerleri açısından doğayı ve çevreyi korumaya, yardımseverliğe, dürüstlüğe daha çok önem veren toplumsal sorunlara duyarlı kişilerin ağırlıklı olarak orta yaş ve üzeri kişiler oldukları görülmüştür. Orta yaş ve üstü kadınlarda duygusal değerin daha çok önemli olduğu görülmüştür. Bu kitle için işletmeler geliştirdikleri çevre dostu ürünlerde fiziksel özellikler yanında duygusal temalara da yer vermeli ve çevrenin zararlı sonuçlarını reklam yoluyla yansıtarak onlarda duygusal durumlar oluşturmalıdırlar. Örneğin çevreci tüketimin iyi bir davranış olduğuna dair reklam sloganlarına ağırlık vermelidirler. Çevre dostu ürünlere yönelik reklamlarda duygusal değerleri harekete geçirecek mesajlara yer verilmesi önerilmektedir. Örneğin, geri dönüştürülebilir ambalajlar (cam şişe vb.) ile çevreye daha az zarar verildiği duygusu oluşturulabilir. Çünkü çevre dostu ürün satın alan kişiler iyi ve doğru olan şeyi yaptıklarını hissetmekte ve çevreyi bu şekilde koruduklarını düşünmektedirler. Araştırma sonucunu dikkate aldığımızda günümüz gençlerinin çevreci üründe kaliteye önem verdiklerini ve çevreyi daha fazla önemsediklerini görmekteyiz. Kısacası gençler çevreci ürünler söz konusu olduğunda onları sadece haz almak için değil, daha kaliteli olduğunu düşündükleri için de aldıkları söylenebilir. Çalışmanın ilerde yapılacak araştırmalara katkıları aşağıdaki gibidir:

İlerde farklı değişkenler dikkate alınarak çevreci tüketicilerin alt grupları incelenebilir. Farklı tüketici ve ürün grupları üzerinde araştırmalar yapılabilir. Farklı coğrafyalardaki bireylerin öne çıkan değerlerinde farklılıklar olabileceği düşüncesinden yola çıkılarak farklı kültürlerde araştırmalar yapılabilir. Farklı tüketim ve kişisel değer grupları açısından araştırmalar yapılabilir. Bu araştırmalara kültürel değerler de dahil edilebilir. Kadınların en çok dikkat ettikleri çevresel ürünlerden birinin de giyim olduğu göz önünde bulundurularak sürdürülebilir moda tüketiminin çevreci tüketim ile ilişkisi araştırılabilir. Araştırmanın geçerliliğini desteklemek adına Doğu Anadolu'da karşılaştırma çalışmaları yapılabilir. Sigaranın çevreye verdiği zarar düşünüldüğünde sigara kullanan/ ara sıra kullanan/ kullanmayan tüketicilerin kişisel değerleri açısından aralarındaki farklılıklar araştırılabilir. Erkeklerin ve tüm değerlerin araştırmaya alınmaması araştırmanın kısıtı olup, ileriki çalışmalara dahil edilerek daha kapsamlı bir analiz yapılabilir. Yaşın çevreci kadın tüketicileri ayırmada anlamlı bir belirleyen olmasından yola çıkılarak, ilerde 
gençler ve orta ve üst yaş grubu tüketiciler üzerinde ayrı ayrı çalışmalar yapılarak kuşaklar arası fark daha ayrıntılı yansıtılabilir. İlerde self-organizing maps (SOM) gibi farklı kümeleme yöntemlerinden yararlanılarak benzer çalışmalar yapılabilir.

\section{KAYNAKÇA}

Alnıaçık, Ü., Yılmaz, C., \& Alnıaçık, E. (2010). Reklamlarda Çevreci Iddialar ve Reklam Etkililiği: Basili Reklamlar Üzerinde Deneysel Bir Araştirma. Anadolu Üniversitesi Sosyal Bilimler Dergisi, 10(1), 85-106.

Ay, C., \& Ecevit Z. (2005). Çevre Bilinçli Tüketiciler. Akdeniz Üniversitesi Iktisadi ve Idari Bilimler Fakültesi Dergisi, 5(10), 238-263.

Bilsky, W., \& Schwartz, S. H. (1994). Values and Personality. European Journal of Personality, 8(3), 163-181. doi: 10.1002/per.2410080303

Byrd, R.R. (2002). Exploring Internet Survey Techniques: A Study of Personal ValuesLeadership Style Congruence. PhD Dissertation. USA: University of Louisville.

Candan, B., \& Y1ldırım, S. (2013). Investigating the Relationship between Consumption Values and Personal Values of Green Product Buyers. International Journal of Economics and Management Sciences, 2(12), 29-40.

Choi, C. C. (2005). Cultural Values in Context: Implications for Behavioral Intentions. PhD Dissertation. USA: University of Illinois.

Demirel, M., Gürbüz, B., \& Karaküçük, S. (2009). Rekreasyonel Aktivitelere Katılımın Çevreye Yönelik Tutum Üzerindeki Etkisi ve Yeni Ekolojik Paradigma Ölçeği'nin Geçerliği ve Güvenirliği. Spormetre Beden Eğitimi ve Spor Bilimleri Dergisi, 7(2), 47-50.

Devrani, T. K. (2010). Kişisel Değerlerin Kuramsal Yapısı ve Pazarlamadaki Uygulamalar. Eskişehir Osmangazi Üniversitesi IIBBF Dergisi, 5(1), 49-70.

Dobre, C., Dragomir, A., \& Preda, G. (2009). Consumer Innovativeness: A Marketing Approach. Management \& Marketing, 4(2), 19-34.

Follows, S. B., \& Jobber, D. (2000). Environmentally Responsible Purchase Behaviour: A Test of a Consumer Model. European Journal of Marketing, 34(5/6), 723-746. doi: 10.1108/03090560010322009

Gilg, A., Barr, S., \& Ford, N. (2005). Green Consumption or Sustainable Lifestyles? Identifying the Sustainable Consumer. Futures, 37(6), 481-504. doi: 10.1016/j.futures.2004.10.016

Grey, C.A.K. (2005). Managerial Ethics: A Quantitative, Correlational Study of Values and Leadership Styles of Veterinary Managers. PhD Dissertation. USA: University of Phoenix.

Grunert, S. C., \& Juhl, H. J. (1995). Values, Environmental Attitudes, and Buying of Organic Foods. Journal of Economic Psychology, 16(1), 39-62. doi:10.1016/01674870(94)00034-8 
Gutman, J. (1982). A Means-End Chain Model Based on Consumer Categorization Processess, Journal of Marketing. 46(2), 60-72. doi: 10.2307/3203341

Hair, J. F., Anderson, R. E., Tatham, R. L., \& Black, W. C. (1998). Multivariate Data Analysis. NY: Prentice Hall International.

Hedlund, T. (2011). The impact of Values, Environmental Concern, and Willingness to Accept Economic Sacrifices to Protect the Environment on Tourists' Intentions to Buy Ecologically Sustainable Tourism Alternatives. Tourism and Hospitality Research, 11(4), 278-288.

Işsldar, G. (2008). Meslek Yüksekokulları Boyutunda Çevre Eğitiminin Çevreci Yaklaşımlar ve Davranışlar Üzerindeki Etkilerinin Değerlendirilmesi. Türk Ĕgitim Bilimleri Dergisi, 6(4), 759-778.

Kalafatis, S. P., Pollard, M., East, R., \& Tsogas, M. H. (1999). Green Marketing and Ajzen's Theory of Planned Behaviour: A Cross-Market Examination. Journal of Consumer Marketing, 16(5), 441-460. doi: 10.1108/07363769910289550

Kamakura, W. A., \& Mazzon, J. A. (1991). Value Segmentation: A Model for the Measurement of Values and Value Systems. Journal of Consumer Research, 18(2), 208-218. doi: 10.1086/209253

Karalar, R., \& Kiraci, H. (2010). Bireysel Değerlerin Sürdürülebilir Tüketim Davranişi Üzerindeki Etkisini Belirlemeye Yönelik Öğretmenler Üzerinde Bir Araştırma. Işsletme Araştırmaları Dergisi, (2), 79-106.

Karp, D. G. (1996). Values and Their Effect on Pro-Environmental Behavior. Environment and Behavior, 28(1), 111-133. doi: 10.1177/0013916596281006

Ko, E., Hwang, Y. K., \& Kim, E. Y. (2013). Green Marketing' Functions in Building Corporate Image in the Retail Setting. Journal of Business Research, 66(10), 17091715. doi: 10.1016/j.jbusres.2012.11.007

Kotler, P. (1997). Marketing Management. Prentice Hall International Inc.

Krystallis, A., \& Chryssohoidis, G. (2005). Consumers' Willingness to Pay for Organic Food: Factors that Affect it and Variation Per Organic Product Type. British Food Journal, 107(5), 320-343. doi: 10.1108/00070700510596901

Kurtuluş, K. (1998). Pazarlama Araştırmaları. İstanbul: Avcıol Basım Yayım.

Leiserowitz, A. A., Kates, R. W., \& Parris, T. M. (2006). Sustainability Values, Attitudes, and Behaviors: A Review of Multinational and Global Trends. Annual Review of Environment and Resources, 31, 413-444. doi: 10.1146/annurev.energy.31.102505.133552

Lin, P. C., \& Huang, Y. H. (2012). The Influence Factors on Choice Behavior Regarding Green Products Based on the Theory of Consumption Values. Journal of Cleaner Production, 22(1), 11-18. doi: 10.1016/j.jclepro.2011.10.002 
Lindeman, M., \& Verkasalo, M. (2005). Measuring Values with the Short Schwartz's Value Survey. Journal of Personality Assessment, 85(2), 170-178. doi: 10.1207/ s15327752jpa8502_09

Mostafa, M. M. (2007). A Hierarchical Analysis of the Green Consciousness of the Egyptian Consumer. Psychology \& Marketing, 24(5), 445-473. doi: 10.1002/mar.20168.

Mueller, S. (2011). Are Personal Values Related to Sustainable Attribute Choice?. PhD Dissertation. University of South Australia.

Özdemir, Ö. (2013). Sürdülebilir Tüketim Davranışlarında Kişisel Değerlerinrolü: Kadın Öğretim Elemanlarının Giysi Elden Çıkarma Davranışları Üzerine Bir Araştırma. Yayınlanmamış Yüksek Lisans Tezi. Adana: Çukurova Üniversitesi.

Ramos, A. (2006). Social Values Dynamics and Socio-Economic Development. Portuguese Journal of Social Science, 5(1), 35-64. doi: 10.1386/pjss.5.1.35/1

Sam, N., Sam R,, \& Öngen B. (2010). Üniversite Öğrencilerinin Çevresel Tutumlarının Yeni Çevresel Paradigma Ölçeği ve Benlik Saygısı Ölçeği ile İncelenmesi. Akademik Bakış Dergisi, 21, 1-16.

Schultz, P. W., \& Zelezny, L. (1999). Values as Predictors of Environmental Attitudes: Evidence for Consistency Across 14 Countries. Journal of Environmental Psychology, 19(3), 255-265. doi:10.1006/jevp.1999.0129

Schultz, P. W., Gouveia, V. V., Cameron, L. D., Tankha, G., Schmuck, P., \& Franěk, M. (2005). Values and Their Relationship to Environmental Concern and Conservation Behavior. Journal of Cross-Cultural Psychology, 36(4), 457-75. doi: $10.1177 / 0022022105275962$

Schwartz, S. H. (1992). Universals in the Content and Structure of Values: Theoretical Advances and Empirical Tests in 20 Countries. Advances in Experimental Social Psychology, 25, 1-65. doi: 10.1016/S0065-2601(08)60281-6

Schwartz, S. H. (1994). Are There Universal Aspect in the Content and Structure of Valores. Journal of Social Issues, 50, 19-45. doi: 10.1111/j.15404560.1994.tb01196.x

Şener, A., \& Hazer, O. (2007). Degerlerin Kadinlarin Surdurulebilir Tuketim Davranisi Uzerindeki Etkilerine Iliskin Bir Araştirma. Hacettepe Universitesi Sosyolojik Araştirmalar E-dergisi, 1-16. (Erişim: http://www.sdergi.hacettepe.edu.tr/makaleler/Arzu_Sener_Oya_Hazer-20-62007.pdf

Sheth, J. N., Newman, B. I., \& Gross, B. L. (1991a). Consumption Values and Market Choices-Theory and Application. USA: South Western Publishing.

Sheth, J. N., Newman, B. I., \& Gross, B. L. (1991b). Why We Buy What We Buy: A Theory of Consumption Values. Journal of Business Research, 22(2), 159-170. doi:10.1016/0148-2963(91)90050-8 
Shim, S., \& Eastlick, M. A. (1998). The Hierarchical Influence of Personal Values On Mall Shopping Attitute and Behavior. Journal of Retailing, 74(1), 139-160. doi:10.1016/S0022-4359(99)80091-8

Stern, P. C., \& Dietz, T. (1994). The Value Basis of Environmental Concern. Journal of Social Issues, 50(3), 65-84. doi: 10.1111/j.1540-4560.1994.tb02420.x

Stern, P. C., Dietz, T., \& Guagnano, G. A. (1998). A Brief Inventory of Values. Educational and Psychological Measurement, 58(6), 984-1001. doi: 10.1177/0013164498058006008

Stern, P. C., Dietz, T., Abel, T. D., Guagnano, G. A., \& Kalof, L. (1999). A Value-BeliefNorm Theory of Support for Social Movements: The Case of Environmentalism. Human Ecology Review, 6(2), 81-97.

Suki, N. M., \& Suki, N. M. (2015). Impact of Consumption Values on Consumer Environmental Concern Regarding Green Products: Comparing Light, Average, and Heavy Users'. International Journal of Economics and Financial Issues, 5, 82-97.

Sweeney, J. C., \& Soutar, G. N. (2001). Consumer Perceived Value: The Development of a Multiple Item Scale. Journal of Retailing, 77(2), 203-220. doi: 10.1016/S00224359(01)00041-0

Thøgersen, J., \& Grunert-Beckmann, S. C. (1997). Values and Attitude Formation Towards Emerging Attitude Objects: From Recycling to General, Waste Minimizing Behavior. Advances in Consumer Research, 24(1). 182-189

Thogersen, J., \& Ölander, F. (2002). Human Values and The Emergence of a Sustainable Consumption Pattern: A Panel Study. Journal of Economic Psychology, 23(5), 605630. doi: 10.1016/S0167-4870(02)00120-4

Ünal, S., Deniz, A., \& Can, P. (2008). Marka Bağlılığı ve Kişisel Değerler Açısından Pazar Bölümleme. Atatürk Üniversitesi İktisadi ve İdari Bilimler Dergisi, 22(1), 211237.

Xiao, G., \& Kim, J. O. (2009). The Investigation of Chinese Consumer Values, Consumption Values, Life Satisfaction, And Consumption Behaviors. Psychology \& Marketing, 26(7), 610-624. doi: 10.1002/mar.20291

Yıldırım, S., \& Candan, B. (2015). Segmentation of Green Product Buyers Based on Their Personal Values and Consumption Values. Environmental Values, 24(5), 641-661. http://dx.doi.org/10.3197/096327115X14384223590212 